\title{
The Elephant in the Room: Europe in the 2015 British General Election
}

La grande absente: l'Europe dans les élections législatives de 2015

\section{Pauline Schnapper}

\section{(2) OpenEdition}

\section{Journals}

Electronic version

URL: http://journals.openedition.org/rfcb/613

DOI: $10.4000 / \mathrm{rfcb} .613$

ISSN: 2429-4373

Publisher

CRECIB - Centre de recherche et d'études en civilisation britannique

\section{Electronic reference}

Pauline Schnapper, «The Elephant in the Room: Europe in the 2015 British General Election », Revue Française de Civilisation Britannique [Online], XX-3 | 2015, Online since 01 December 2015, connection on 20 April 2019. URL : http://journals.openedition.org/rfcb/613; DOI : 10.4000/rfcb.613

This text was automatically generated on 20 April 2019.

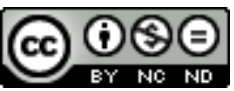

Revue française de civilisation britannique est mis à disposition selon les termes de la licence Creative Commons Attribution - Pas d'Utilisation Commerciale - Pas de Modification 4.0 International. 


\title{
The Elephant in the Room: Europe in the 2015 British General Election
}

\author{
La grande absente: l'Europe dans les élections législatives de 2015
}

\section{Pauline Schnapper}

Europe has been a divisive issue in British politics for at least three decades, when the ratification of the Maastricht treaty opened divisions in the Conservative party after decades during which Labour had been split on the question. Yet it has usually played a very limited, if not insignificant, role in British general elections. When asked about their main concerns, voters hardly ever mention Europe, but rather domestic issues such as the economy, the NHS and immigration. 2015 was no exception to this rule, with only $6 \%$ of voters mentioning the European Union (EU) as the most important issue for them, in spite of the apparent rise of euroscepticism in the country. ${ }^{1}$ Politicians know that they have little to gain therefore from tackling the issue, as William Hague learnt the hard way when he tried to campaign to "Keep the Pound" against New Labour in 2001, and made no electoral gain out of it.

Yet the 2015 general election could have been different because this time, the outcome of the election was going to have dramatic consequences on the future of Britain in the EU. In a speech on 23 January 2013, David Cameron had promised to organise an in/out referendum by the end of 2017 should the Conservatives win a majority in the House of Commons in 2015. This was the result of on-going pressure both from some of his own backbenchers and from UKIP, which made spectacular gains in second-order elections between 2010 and 2015. Neither Labour nor the Liberal Democrats had matched this pledge, so the outcome of the general election could potentially change the course of the history of Britain in Europe.

A debate on the EU could have been organized during the campaign, but this did not happen. Beyond voter lack of interest, none of the three mainstream national parties wished to say much about the EU for a number of reasons that will be explored in this article. Europe was therefore very much the elephant in the room, looming large over the campaign but hardly mentioned until the day after the election. 
In order to explore both the importance of the issue and its low salience, I will first briefly recall the process by which, in the course of the five years of coalition government, Europe became again a divisive issue in the Conservative party, leading the government to gradually become marginalised in the EU in ways which were not very different from what happened under the last Conservative government, under John Major (1990-97). The second section will look at the campaign itself and the way parties used or avoided the issue. Finally, I will try to assess the consequences of the Conservative victory over the prospect of "Brexit", or British exit from the European Union.

\section{Party Pressure and the Road to Isolation}

David Cameron had tried to please the growing number of eurosceptics in his party in opposition as early as his election as leader in 2005. He had pledged that Conservative members of the European Parliament would leave the centre-right European People's Party, deemed too federalist, to establish a new eurosceptic but not extreme-right grouping. When the Lisbon treaty was signed by the Brown government in 2007, he had demanded a referendum and when this proposal was turned down, William Hague, the shadow Foreign Secretary, promised "not to let matters rest there", although what he meant by this exactly was never clarified. Indeed Cameron abandoned the pledge when the Lisbon treaty was ratified by all other member states, much to the dismay of his radical eurosceptic backbenchers. He was therefore already on the defensive when he pledged in the 2010 manifesto to introduce a bill in Parliament which would require any new transfer of power to Brussels to be subject to a referendum (Conservative Party 2010: 113). The party would also campaign for a repatriation of powers to the national level in three areas: the Charter of Fundamental Rights, criminal justice and social legislation (p. 114). There was no mention of an in/out referendum at that stage or of other policies which should be repatriated.

The Liberal Democrats agreed to the "referendum lock" clause in the coalition document signed in May 2010 (HM Government 2010). In this case as on other European issues, their attitude was low-key and their influence limited during the five-year coalition: when it came to Europe, the difficult 'coalition' seemed to be between hard and soft Conservative eurosceptics rather than between the two parties in power. The "lock" was duly introduced in Parliament in the European Union Bill, which became an Act in 2011. But it was not enough to satisfy the hardline eurosceptics, in particular the veteran MP Bill Cash, who headed the EU Scrutiny Committee, and pressure grew within the party in favour of an in/out referendum. ${ }^{2}$ In October 2011, a motion was introduced by David Nuttall, a hard eurosceptic who was part of the new intake of Conservative MPs, following an e-petition asking for a referendum which had gathered more than 100,000 signatures. At that time the government was adamantly against the idea and imposed a three-line whip on the vote. This did not prevent the first major rebellion on Europe since Maastricht, with 81 Conservative MPs voting in favour of the motion (D'Ancona 2014, p. 243-244).

This domestic context explains to a large extent the first crisis between the Cameron government and its European partners at the December 2011 European Council. The Prime Minister had already refused to take part in the bail-out packages for countries such as Portugal and Spain which were affected by the sovereign-debt crisis. This time, he opposed - without discussing it with Nick Clegg, his pro-European coalition partner - the 
fiscal compact proposed by the other member-states in order to strengthen the coordination of budgetary policies within the eurozone. Although not a member of the eurozone and therefore not directly affected, he argued that it would be detrimental to the interests of the City of London. This was hardly the 'veto' that he claimed, since the other EU states went ahead with the plan outside the EU institutions, but it was a clear signal that the British approach to EU affairs would be much more negative than under the previous New Labour governments.

In July 2012, Cameron took a further step to attempt to placate the Conservative eurosceptics, some of whom were tempted to defect to UKIP. The government announced that a "review of the balance of competences" between the national government and the EU would be conducted across the different ministerial departments. This would examine for each area whether the balance was right or whether the government should attempt to repatriate powers to the national level. It would inform future decisions taken by the government. The irony of this exercise, completed in summer 2014, was that its conclusions were broadly positive about the European Union and the balance between Brussels and London, leading it to be quietly shelved and hardly commented on in the (mostly eurosceptic) press. ${ }^{3}$

Cameron's failure to please the hard eurosceptics became even more visible when on 31 October 2012 the government suffered its first parliamentary defeat on the EU budget. Conservative hard eurosceptics joined Labour MPs in voting for a sharp reduction in the EU budget, ringing enough bells in 10 Downing Street to prompt David Cameron to give in on the prospect of a referendum. On 23 January 2013, Cameron delivered a speech in the London Bloomberg headquarters where he promised a renegotiation of the terms of British membership of the EU if he won the 2015 general election, followed by an in/out referendum in the UK by the end of 2017 (Cameron 2013). He mentioned the need for more flexibility in Europe, less regulation and more power for national parliaments. The parallel with Harold Wilson's tactics to keep the Labour Party united behind him in 1974-75 was obvious and, indeed, his U-turn was very well received by Tory backbenchers, who had attempted to introduce a number of Private Members' bills with similar aims. ${ }^{4}$

In the run up to the lifting of restrictions on the free circulation of Romanians and Bulgarians in the EU on 1 January 2014, the issue of EU migrants came to the fore of the British debate, leading Cameron to contemplate imposing controls on EU migration, which is unlawful under the Single European Act. ${ }^{5}$ As German Chancellor Angela Merkel reacted angrily that this could not happen, he backtracked and suggested first imposing restrictions on so-called 'benefit tourism', then in late 2014 restricting migrants' access to welfare for several years (Cameron 2014). By then, he was under growing pressure from UKIP, which in May 2014 had won the European elections and in the autumn secured the defection of two Conservative MPs, thereby gaining its first two parliamentary seats.

Cameron's second and equally unsuccessful battle with his European partners came after the May 2014 European elections. New rules to make EU institutions more accountable had been adopted in the Lisbon treaty, by which the main parties in the European Parliament would choose a 'leader' who would then be appointed as the new President of the European Commission if his/her party won a majority of seats in the European Parliament elections. The leader of the EPP, which won the highest number of seats in May 2014 was Jean-Claude Juncker, the former Prime Minister of Luxemburg. David Cameron decided to oppose his appointment, arguing that it 'shouldn't be the 
Parliament's role, but the heads of state and governments', to appoint the President of the Commission and that Juncker, as a federalist and representative of unpopular oldstyle Brussels politics, was not a suitable candidate. ${ }^{6}$ But he failed to find allies in the EU, in spite of early signals from Merkel as well as the Swedish and Dutch Prime Ministers that they might not support Juncker. In the end, he called for a formal vote in the June European Council in which he was outnumbered by 26 to 2, with only Hungary supporting him. ${ }^{7}$

By the time of the 2015 general election, David Cameron had therefore given in to his eurosceptic backbenchers by committing his party to a referendum on "Brexit", although he made clear he expected to win enough concessions from his partners to call for a yes vote to stay in the EU. At the same time and in apparent contradiction, he had antagonised many of his European neighbours with a negative attitude to EU attempts to strengthen integration in the midst of a deep economic crisis. He made few friends in the EU in the process and lost those he had had in the past, Northern and Eastern Europeans who would normally share his Atlanticist and economically liberal views but rejected his anti-immigration rhetoric. He faced an uphill struggle to reverse the marginalisation of his country in the EU and extract concessions from them.

\section{The Campaign}

On the day after the 7 May general election, the political debate returned immediately to Europe and Cameron's promise to organise a referendum, which was announced in the Queen's speech on 27 May, illustrating how crucial the issue was. Yet this stood in stark contrast to the campaign itself, where Europe was hardly present, at least in the mainstream parties' campaign.

As we have seen, David Cameron had agreed to a referendum in part to avoid eurosceptic pressure during the campaign and limit the damage UKIP could do to his electoral chances. The Conservative manifesto therefore insisted that the party would "give you a say over whether we should stay in or leave the EU", but it was short on substantive issues, except to pledge to "reform the workings of the EU, which is too big, too bossy and too bureaucratic; reclaim power from Brussels on your behalf and safeguard British interests in the Single Market" (Conservative Party 2015). There was no need to be more explicit at that stage, and the less the EU was talked about during the campaign, with Conservative divisions papered over in the short term, the less UKIP could pressurize and divide the Tories. There was no discussion of the reforms which would need to be agreed in order to support staying in the EU and Cameron was not really pushed on the issue by other parties or journalists.

Their coalition partners, the Liberal Democrats, declined to promise an in/out referendum, although in 2007 they were in favour of a referendum on the Lisbon treaty, which they supported, but were not keen to raise the issue. Traditionally more proEuropean than the two other main parties, and indeed than the British public at large, they had also had a bruising experience when Nick Clegg confronted Nigel Farage, the UKIP leader, in two televised debates in April 2014, which Clegg was widely seen as having lost. ${ }^{8}$ Europe was not a vote-winner for the Lib Dems and their manifesto mainly repeated a very general pro-EU stance, qualified by equally vague criticism of the way the EU worked, a view supposedly in tune with the mood of the country: 
Liberal Democrats want Britain to remain a member of the EU because we are fighting for a stronger economy and British jobs... But that doesn't mean the European Union is perfect: far from it. Liberal Democrats want to reform the EU so that it concentrates on doing the things it's good at such as creating jobs, fighting climate change and combating cross-border criminal gangs, but stays out of decisions better decided at national, devolved or local levels.(Liberal Democrats 2015)

During the campaign, Clegg softened his opposition to the idea of a referendum, saying he might accept it provided a number of conditions were met. ${ }^{9}$ He was by then hoping to be in a position to negotiate another coalition with the Conservatives after the election, and therefore wanted to keep all options open, knowing that this would be a red line for the Tories.

The Lib Dem manifesto was not very different from Labour's, which stated that "because Britain will be better off remaining at the heart of a reformed EU, Labour will make the hardheaded, patriotic case both for reform in Europe, not exit from Europe" (Labour Party 2015). Ed Miliband, its leader since 2010, insisted, like the Liberal Democrats, on the folly of "Brexit" . But he was more on the defensive on this issue than Clegg because he had resisted the pressure from inside and outside his own party to match Cameron's promise to organise a referendum. ${ }^{10} \mathrm{He}$ had therefore no reason to make too much of the European issue, on which he risked being accused of refusing a democratic vote. Indeed he appeared awkward and uncomfortable when confronted on why he refused a referendum on EU membership by a factory worker on the campaign trail in Lancashire. ${ }^{11}$ The two Labour voices that were heard about Europe during the campaign were those of Gordon Brown and Tony Blair, the ex-Prime Ministers, neither of whom stood anymore for election. Brown published a pro-EU article in the Guardian and Tony Blair delivered a speech criticising the Conservatives over Europe in his former Sedgefield constituency. ${ }^{12}$

As a result of the mainstream parties' reluctance to mention the EU in the campaign, this was left to what we call the successful insurgent parties in this journal issue, i.e. UKIP and the Scottish National Party (SNP), although for different reasons. A British withdrawal from the EU has been UKIP's raison d'être since it was created in 1993. Its whole 2015 manifesto was based on the idea that this would solve all of Britain's problems, in particular immigration, the economy and the NHS, as the first line of its introduction clearly showed: "This manifesto is our blueprint for a Britain released from the shackles of the interfering EU" (UKIP 2015). In the general election, Farage was hoping to gain at least a handful more MPs on top of the two he had gained in 2014. In case of a hung Parliament, he might be able to bargain his support for a minority Conservative government in exchange for an immediate referendum on 'Brexit'. Mentioning Europe was also a way to increase pressure on the Conservatives, who feared losing voters to UKIP in the south of England.

In the case of the SNP, Europe was one area where the party could distance itself from all unionist parties by making an unambiguously pro-European case. The manifesto opposed withdrawal from the EU without the qualifications of Labour or the Lib Dems' document:

At least 330,000 Scottish jobs - around one in seven of all jobs - are dependent on our membership of the single market. That is why we will oppose a referendum on membership of the EU. Being part of Europe is good for business and it supports jobs in Scotland and across the UK. (SNP 2015)

Europe was also a useful tool to strengthen the nationalists' case for independence. They were able to turn the relatively more pro-European views of many Scots, confirmed in a 
number of polls, to their advantage. ${ }^{13}$ The simple argument was that if there was to be a referendum in the UK about leaving the EU, the only certain way for Scots to remain in the EU was to vote SNP and to support Scottish independence. Nicola Sturgeon repeated several times that in case of Brexit, all parts of the UK should vote for it, asking effectively for a Scottish veto in the referendum - which she knew the British government would never accept. ${ }^{14}$ In the Scottish leaders' debate on 9 April, she explicitly threatened to demand a second referendum on Scottish independence if the UK voted to leave the EU. ${ }^{15}$ Europe was therefore once again a tool in the SNP's overall strategy to distance itself from Westminster politics and policies. ${ }^{16}$

\section{Is Brexit more likely?}

The immediate effect of the general election results was that, with the new Conservative overall majority in the House of Commons, a referendum on the future of Britain in the $\mathrm{EU}$ is no longer just possible but now certain. David Cameron confirmed that it will take place by the end of 2017 and possibly earlier, depending on the negotiations he is going to start with his European partners. After Ed Miliband's resignation from the Labour leadership, the party opted to support the referendum. The Queen's speech announced that:

My government will renegotiate the United Kingdom's relationship with the European Union and pursue reform of the European Union for the benefit of all member states. Alongside this, early legislation will be introduced to provide for an in-out referendum on membership of the European Union before the end of 2017. ${ }^{17}$

The Prime Minister started a tour of European capitals to lay out a general list of UK demands, without being too specific. Issues often mentioned involved a possible opt out from the aim of 'ever closer union' which is in the European treaties; completing the single market and protecting the interests of the City; curbing welfare access for immigrants. This was meant to keep him some room for manoeuvre both for the negotiations and domestically. It was also a far cry from the ideas about fundamental change in the relationship with the EU or the repatriation of substantial powers from Brussels which had often been aired in the past, and this made success in the negotiations more likely or less unlikely in the future. Similarly, it became clear as early as the 26 June European Council, that there would be no treaty change in the EU before the referendum took place.

Cameron's main difficulty is going to be to find a compromise between what the radical eurosceptics demand and what the European Union member states are able and willing to grant him. At the moment the gap between the two looks difficult to bridge, so he will aim to obtain enough substantial and symbolic concessions in Brussels to convince, not so much the anti-Europeans, as enough British voters to win the referendum. Indeed, like Wilson in the 1970s, resorting to a referendum is not just a way to please opponents to membership of the EU but also the means to bypass their opposition, going directly to 'the people'. But another possible comparison is with the Major years. Like Major after the 1992 general election, Cameron's majority is already very small. This could give extra leverage to the eurosceptic backbenchers, like Major's 'bastards' then, to harass the government. Furthermore, some radical eurosceptics, like Iain Duncan Smith or Boris Johnson (who has sent ambiguous signals on the topic of Brexit) sit in the Cabinet, which 
was not the case in the 1990s. Cameron will have to walk a fine line to maintain at least some of them on board in the run up to the referendum.

The outcome of the ballot is of course impossible to forecast in 2015. Opinion polls in 2014 and 2015 showed a slight majority of voters in favour of staying in the EU, especially if the government achieved a successful negotiation. ${ }^{18}$ But the general election showed that polls were not always reliable. Furthermore, much will depend on Cameron's results in the negotiations, the popularity of his government when the vote takes place, the Greek crisis and the state of the eurozone economies, the strengths and weaknesses of the future 'yes' and 'no' campaigns, that is a mixture of domestic and European factors. A period of political uncertainty for Britain and for the EU has started.

\section{Conclusion}

Europe is going to dominate British political debate until the referendum on membership of the EU takes place sometime in 2016 or 2017. Yet the merits or otherwise of membership were never discussed during the campaign, except by Nigel Farage, the UKIP leader, and Nicola Sturgeon, the SNP leader, two parties which were unlikely to become part of the UK government but exercised strong pressure on the traditional political system. None of the main three party leaders saw any compelling reason to mention it on the doorsteps or in the national medias, both because voters did not seem interested and because, for different reasons, they were all on the defensive and preferred to avoid talking about Europe altogether, thereby postponing the discussion to a future referendum campaign. Europe remains more than ever a difficult question in British politics, bringing trouble to all mainstream parties. They therefore choose the conservative attitude of not mentioning it when they can rather than engaging the public.

\section{BIBLIOGRAPHY}

CAMERON, David, “EU speech at Bloomberg”, 23 January 2013, https://www.gov.uk/government/ speeches/eu-speech-at-bloomberg, accessed 29 June 2015.

CAMERON, David, speech about immigration, 28 November 2014, http://www.bbc.com/news/ukpolitics-30250299, accessed 29 June 2015.

CONSERVATIVE PARTY (2010), Invitation to Join the Government of Britain, Conservative Party Manifesto, available at https://www.conservatives.com/ /media/files/activist\%20centre/press\% 20and\%20policy/manifestos/manifesto2010, accessed 23 June 2015.

CONSERVATIVE PARTY (2015), Strong Leadership, A Clear Economic Plan, A Brighter, More Secure Future, Conservative Party Manifesto, https://s3-eu-west-1.amazonaws.com/manifesto2015/ ConservativeManifesto2015.pdf, accessed 30 June 2015.

D'ANCONA, Matthew. In It Together: The Inside Story of the Coalition Government, London, Penguin Books, 2014, 480 p. 
HM GOVERNMENT (2010), The Coalition: Our Programme for Government, available at https:// www.gov.uk/government/uploads/system/uploads/attachment_data/file/78977/ coalition_programme_for_government.pdf, accessed 23 June 2015.

LABOUR PARTY (2015), Britain can be better, Labour Party Manifesto, http://www.labour.org.uk/ page/-/BritainCanBeBetter-TheLabourPartyManifesto2015.pdf, accessed 30 June 2015.

LEYDIER, Gilles. «L'Europe, une ressource politique pour le SNP » pp 47-62 in Agnès ALEXANDRECOLLIER, Bernard D'HELLENCOURT and Pauline SCHNAPPER (eds.), Le Royaume-Uni et l'Union européenne depuis 1997, Dijon, Editions Universitaires, 2007.

LIBERAL DEMOCRATS (2015), Stronger Economy, Fairer Society, Opportunity for Everyone, Liberal Democrats Manifesto, http://ucrel.lancs.ac.uk/wmatrix/ukmanifestos2015/localpdf/ LiberalDemocrats.pdf, accessed 30 June 2015.

LYNCH, Philip. "The Con-Lib Agenda for Europe” pp. 218-236 in Simon LEE and Matt BEECH (eds.), The Cameron-Clegg Government, Basingstoke, Palgrave, 2011.

SCHNAPPER, Pauline. "New Labour, Devolution and British Identity : the Foreign Policy Consequences", pp. 48-62 in Oliver DADDOW and Jamie GASKARTH (eds.), British Foreign Policy: The New Labour Years, Basingstoke, Palgrave, 2011.

SCHNAPPER, Pauline. "The Labour Party and Europe from Brown to Miliband: Back to the Future", Journal of Common Market Studies, vol. 53, n²1, 2015, pp. 157-173.

SMITH, Julie. "Europe: The coalition's poisoned chalice", pp. 370-396 in Anthony SELDON and Mike FINN (eds.), The Coalition Effect, Cambridge University Press, 2015.

SNP (2015), Stronger for Scotland, SNP manifesto, http://votesnp.com/docs/manifesto.pdf, accessed 30 June 2015.

UKIP (2015), Believe in Britain, UKIP Manifesto, http://ukip-serv.org/theukipmanifesto2015.pdf, accessed 30 June 2015.

\section{NOTES}

1. The Guardian, 20 January 2015.

2. Julie SMITH, "Europe: The coalition's poisened chalice" in Anthony SELDON and Mike FINN (eds.), The Coalition Effect, Cambridge University Press, 2015, p. 383; Philip LYNCH, "The Con-Lib Agenda for Europe" pp. 218-236 in Simon LEE \& Matt BEECH (eds.), The Cameron-Clegg Government, Palgrave, 2011.

3. The reports can be found at https://www.gov.uk/government/news/final-reports-in-reviewof-eu-balance-of-competences-published, accessed 1 July 2015. See also Simon USHERWOOD, 'Hand-waving as renegociation: the UK's (and EU's) limited options', http://blogs.lse.ac.uk/ europpblog/2013/09/26/hand-waving-as-renegotiation-the-uks-and-eus-limited-options/, $\quad 26$ September 2013, accessed 23 June 2015.

4. See http://www.conservativehome.com/the-jury/2013/01/what-did-you-think-of-davidcamerons-europe-speech.html, accessed 29 June 2015.

5. David CAMERON, "Free movement within Europe needs to be less free", Financial Times, 26 November 2013.

6. "Juncker is wrong person for European Commission job, says David Cameron", The Guardian, 27 June 2014.

7. “David Cameron loses Jean-Claude Juncker vote”, The Guardian, 27 June 2014. 
8. "Farage vs Clegg: UKIP leader triumphs in second televised debate", The Guardian, 3 April 2014. The second debate can be watched on https://www.youtube.com/watch?v=fd9rsmD4HiM.

9. "Nick Clegg set to exact steep price for backing EU referendum", Financial Times, 31 March 2015.

10. "Ed Miliband set for decision on Europe referendum", The Guardian, 19 May 2012.

11. "Ed Miliband confronted by working class voter over Europe", Daily Telegraph, 19 February 2015.

12. Gordon BROWN, "The truly patriotic British view on Europe? We must lead from within", The Guardian, 9 March 2015; "Tony Blair backs Ed Miliband and warns of EU chaos if Tories win election”, The Guardian, 7 April 2015.

13. See for instance the British Future poll showing that over $50 \%$ of Scots would vote in favour of staying in the EU against 33\%, quoted in The Scotsman, 6 June 2015.

14. "Scotland should have veto on UK exit from EU, says Sturgeon", Financial Times, 29 octobre 2014.

15. http://www.bbc.co.uk/iplayer/episode/b05tv6dm/the-leaders-debate.

16. Gilles LEYDIER, "L'Europe, une ressource politique pour le SNP » pp. 47-62 in Agnès ALEXANDRE-COLLIER, Bernard D'HELLENCOURT and Pauline SCHNAPPER (eds.), Le Royaume-Uni et l'Union européenne depuis 1997, Dijon, Editions Universitaires, 2007 ; Pauline SCHNAPPER, "New Labour, Devolution and British Identity : the Foreign Policy Consequences" pp. 48-62 in Oliver DADDOW and Jamie GASKARTH (eds.), British Foreign Policy: The New Labour Years, Palgrave, 2011.

17. Queen's speech 2015, https://www.gov.uk/government/speeches/queens-speech-2015, accessed 1 July 2015.

18. At the time of writing, the latest poll available gave $45 \%$ of respondents in favour of staying and $35 \%$ for leaving. See https://yougov.co.uk/news/2015/04/22/eu-referendum-lead-10/, accessed 1 July 2015.

\section{ABSTRACTS}

Europe was hardly mentioned by the mainstream parties in the 2015 general election campaign in spite of the fact that its outcome was going to have a dramatic impact on whether an in/out referendum was going to be organised in the UK or not. For different reasons, it was not in the interest of either the Conservatives, Labour or the Liberal Democrats to make much use of the issue, leaving it to UKIP and, to a certain extent the SNP. In contrast to the election campaign, Europe is now going to dominate the political debate until the referendum takes place in 2016 or 2017.

La question européenne a été peu abordée par les principaux partis politiques britanniques pendant la campagne législative de 2015 malgré les conséquences importantes du résultat sur l'organisation ou non d'un référendum sur le maintien dans l'UE. Pour des raisons différentes, ni les Conservateurs, ni les Travaillistes ni les Libéraux-démocrates n'avaient intérêt à en parler,ce qui a laissé le champ libre à UKIP et dans une moindre mesure le SNP. Contrairement à ce qui s'est passé pendant la campagne, l'Europe va dominer le débat politique outre-Manche jusqu'au référendum, en 2016 ou 2017. 
INDEX

Mots-clés: Union européenne, référendum, parti conservateur, Brexit, UKIP

Keywords: European Union, referendum, Conservatives, Brexit, UKIP

\section{AUTHOR}

PAULINE SCHNAPPER

Université de la Sorbonne Nouvelle Paris 3 